\title{
Mineral balances, including in drinking water, estimated for Merced County dairy herds
}

by Alejandro R. Castillo, José E.P. Santos and Tom J. Tabone

Dairy producers must increasingly comply with environmental regulations at the federal, state and local levels. A key to many of the regulations is the development of manure management plans to protect air, water and soil quality. Information on complete nutrient balances and excretion is necessary to control or minimize the loss of nutrients to the environment. Data from 51 randomly selected dairy farms in Merced County, in California's Central Valley, was used to evaluate the impact of minerals in drinking water on nutrient balances and to characterize the mineral composition of manure from lactating dairy cows. We found that a lactating dairy cow producing approximately 66 pounds of milk daily might excrete $750 \pm 117$ grams of minerals daily, while the proportion of these minerals attributed to water ranged from $0.3 \%$ to $20 \%$. On some dairies, controlling these minerals could reduce manure production and subsequent land applications.

IN recent years, environmental regulations have been applied to the U.S. dairy industry. These regulations are aimed at protecting air, water and soils from excess nutrients excreted by cattle and manure applications. The National Pollutant Discharge Elimination System (NPDES) prohibits the discharge of pollutants into waters of the United States unless a special permit is issued by the U.S. Environmental Protection Agency (EPA). In 2003, this law was extended to confined animal feeding operations (CAFOs), including most dairies; many of the deadlines were extended to 2007.

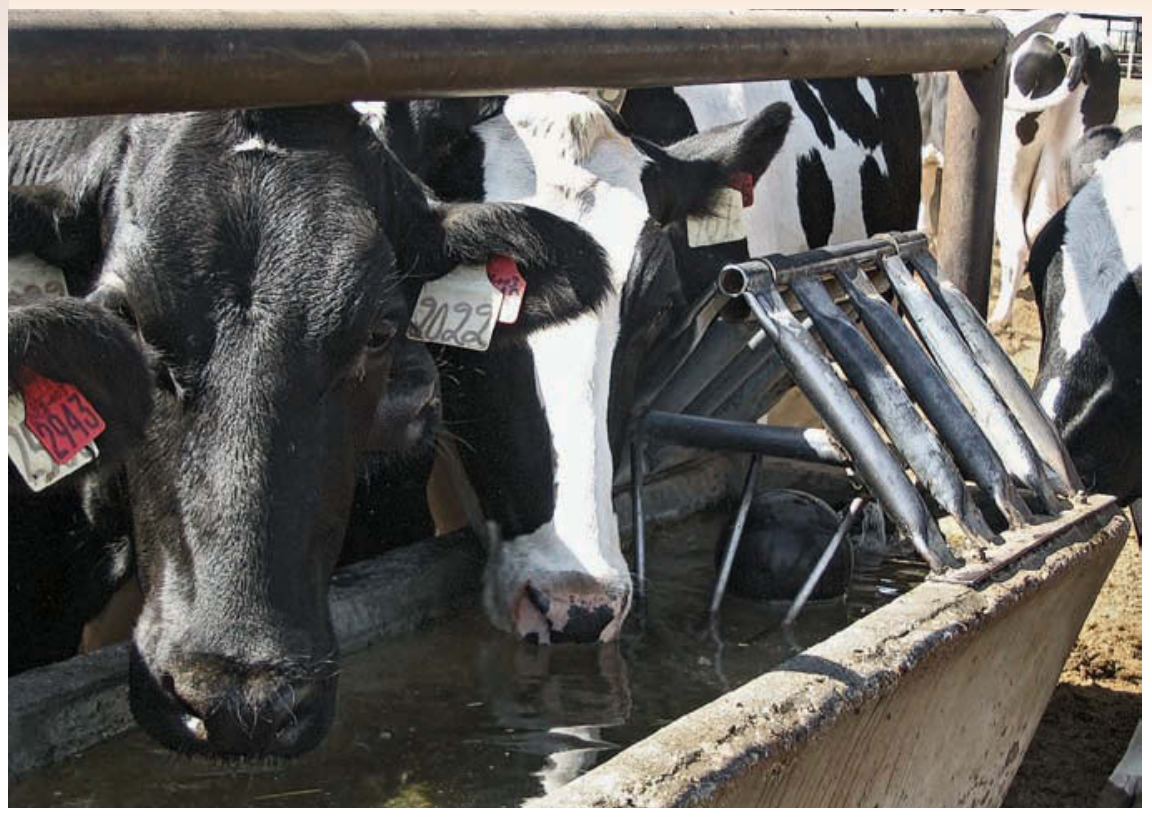

New laws require dairy producers to control manure applications and limit the excretion of excess nutrients, in order to prevent pollution of the air, water and soils. Water is the most important nutrient for dairy cattle, but its mineral contents are not usually incorporated when animal diets are planned.

In general, this permit system is enforced by California's Regional Water Quality Control Boards and various county ordinances. All dairy farms represent possible "discharges"; most producers have submitted Waste Management Plans to their regional board providing a complete evaluation of the existing dairy (facilities, animals, waste containers, flood protection, and so on) (US EPA 2004).

Furthermore, under guidelines developed by the U.S. Department of Agriculture's Natural Resources Conservation Service, certain animal feeding operations must develop Comprehensive Nutrient Management Plans (CNMPs). For dairies, the plans describe how management practices will be implemented to control nutrient losses from manure. The plans detail how dairy producers must apply manure, bedding or process water to the soil at agronomic rates, according to the chemical composition of the manure, local soil conditions and specific crop requirements. The enforcement and even application of CNMP rules vary by county, depending on local conditions (USDA 2003).
Given these new requirements, the American Society of Agricultural Engineers recently concluded that it is essential to improve predictions of nutrient excretion from dairy cattle, so that consultants and producers can develop nutrient management plans for individual farms (Nennich et al. 2005). Software developed by the National Research Council (NRC 2001) in conjunction with its Nutrient Requirements of Dairy Cattle report is considered one of the most current tools for estimating nutrient balances and excretion.

\section{The importance of water}

According to the NRC, water is the most important nutrient for lactating dairy animals. However, good-quality water is a scarce commodity in many areas of the United States and the world (Murphy 1992). In the United States, the availability of abundant, clean, drinking water may become a challenge in the future as dairy farms are forced to relocate away from population centers (Beede 2005). Water contaminants can also affect animal performance and health (Challis et al. 1987; Solomon et al. 1995; NRC 2001). Information is needed 


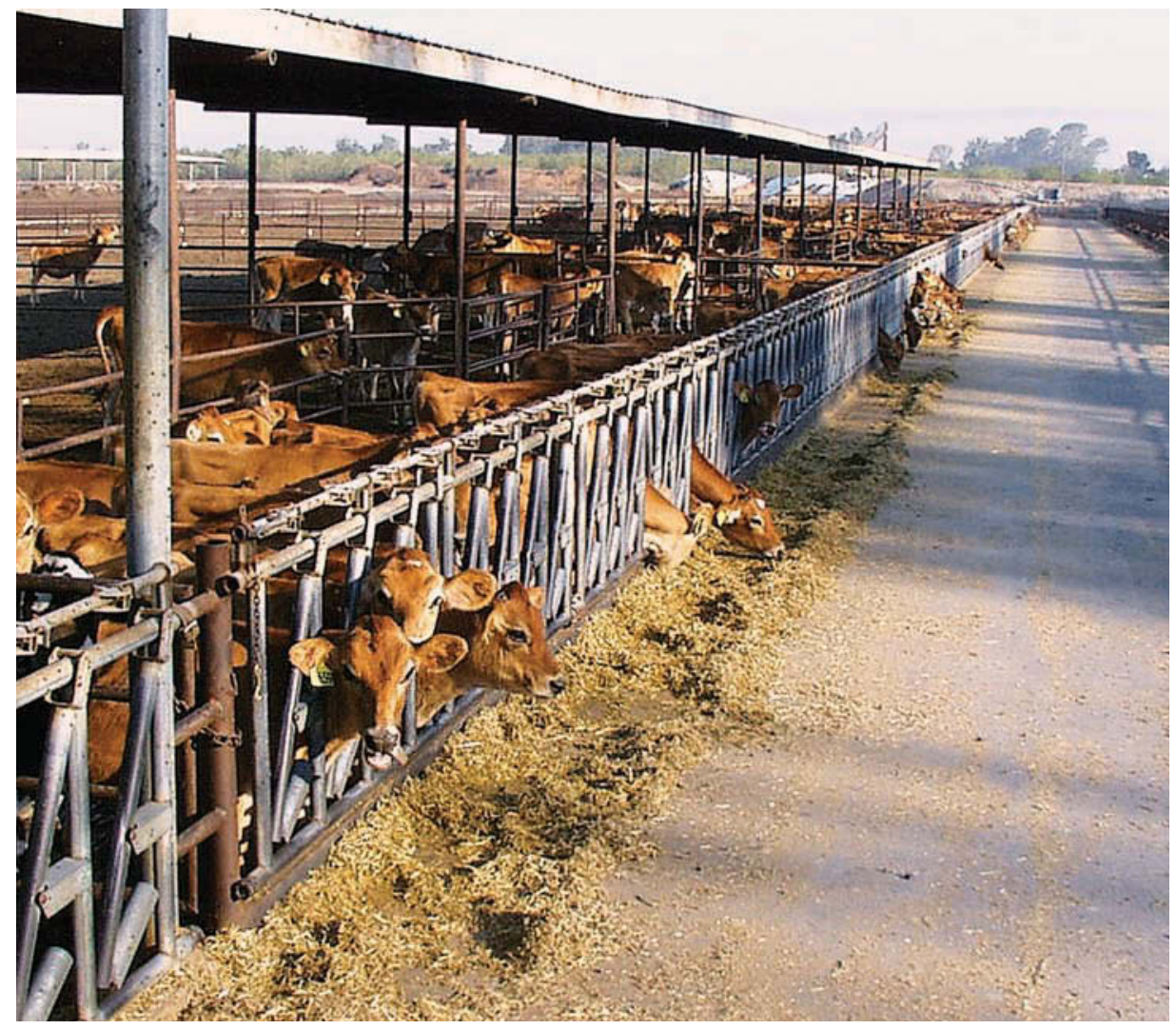

The mineral balances and excretion of lactating dairy cattle on 51 Merced County farms were estimated based on analyses of the animals' diets and drinking water, using a model developed by the National Research Council.

on intensive and high animal production dairies systems in California.

The lack of controlled research studies makes it difficult to evaluate the importance of water quality in dairy herds (Chase 2002; Socha et al. 2002). When formulating diets for dairy cows, some nutritionists ordinarily do not take into account the mineral content of water, because there is a belief that these minerals are of limited biological availability. However, minerals in water can, in some situations, be more biologically available than those in feeds (NRC 2001). Lactating animals generally get water from three sources: (1) drinking water consumed voluntarily, (2) water present in feeds and (3) water formed within the body as a result of oxidation processes. The first two are the most important; for practical purposes, together they represent total water intake.

Feeding certain minerals in excess of the cow's nutritional requirements may lead to environmentally damaging runoff and the application to land of animal wastes containing high mineral concentrations. The prediction of mineral excretion in dairy animals and the chemical composition of manure need to be considered as important as protein or energy dietary balances. This paper presents part of a survey on feeding management and nutrient balances carried out on dairy herds in Merced County. The aim of this work was to estimate mineral balances and mineral excretion in lactating animals, including the minerals in the drinking water, according to mineral requirements of the NRC (2001) for dairy cattle.

\section{Dairy farm study}

From February 2003 to March 2004, 51 dairy farms were randomly selected, and dairy producers were contacted by phone or visited directly. All dairies were visited one or more times to obtain information about nutritional management, herd characteristics and diet composition, and to sample water and concentrated feeds (grains, byproducts, minerals and vitamins mixes).

The NRC software for dairy cattle was used to calculate mineral balances. The final mineral balance to estimate daily excretion for each mineral was obtained as indicated by the software output on the difference between the total dietary supplies (TDS) and the total absorbed required (TAR) for pregnancy, lactation and growth. The TAR for maintenance components (fecal, urinary, sweat and miscellaneous losses) is removed from the body and under normal conditions is excreted daily and replaced with new dietary minerals.

The minerals in water consumed by the cows were estimated based on the water's mineral contents and daily drinking water intake, which was calculated using the formula recommended by the NRC (Murphy 1983). Mineral excretions were calculated for lactating animals in different production groups or diets (for example, fresh cows, first lactation, and low, medium and high milk yields) and by farm, according to the proportion of animals in each production group. The mineral composition of silages and hays was based on the NRC (2001) database. Samples of mixedconcentrate feeds (grains, byproducts, minerals and vitamin premixes) and water were analyzed for total soluble salts (TSS) and the following minerals (listed according to the amounts [grams and milligrams] that are needed): calcium $(\mathrm{Ca})$, phosphorus $(\mathrm{P})$, magnesium $(\mathrm{Mg})$, potassium $(\mathrm{K})$, sodium $(\mathrm{Na})$, chloride $(\mathrm{Cl})$, sulfur $(\mathrm{S})$, sulfate, copper $(\mathrm{Cu})$, iron $(\mathrm{Fe})$, manganese $(\mathrm{Mn})$, selenium (Se) and zinc (Zn); reference methods of the U.S. Environmental Protection Agency (EPA) were used.

\section{Dietary characteristics}

The average daily milk production per farm in this survey was $68 \pm 11.7$ pounds per cow $(30.9 \pm 5.31$ kilograms per cow) ranging from 42 to 95 pounds per cow; and the average daily drymatter intake (DMI) per farm was $48 \pm 4.8$ pounds per cow ( $21.8 \pm 2.2$ kilograms per cow), ranging from 35.8 to 57.6 pounds per cow. The average number of lactating animals per dairy was 809 , ranging from 110 to 5,010, with a median of 523 cows.

In more than $75 \%$ of the farms, the diets of lactating cows were based on just five ingredients: corn silage, alfalfa hay, processed corn grain, whole 


\begin{tabular}{|c|c|c|c|}
\hline \multicolumn{4}{|c|}{$\begin{array}{l}\text { TABLE 1. Main feeds used for lactating cows } \\
\text { on Merced County dairy farms }(n=51)\end{array}$} \\
\hline$\%$ farms & Forages & Grains & $\begin{array}{l}\text { Proteins and } \\
\text { byproducts }\end{array}$ \\
\hline$>75$ & $\begin{array}{l}\text { Corn } \\
\text { silage, } \\
\text { alfalfa } \\
\text { hay }\end{array}$ & $\begin{array}{l}\text { Corn } \\
\text { grain, } \\
\text { cotton } \\
\text { seeds }\end{array}$ & Canola meal \\
\hline 50 to 75 & & & Almond hulls \\
\hline 25 to 50 & $\begin{array}{l}\text { Wheat } \\
\text { and/or } \\
\text { oat hay, } \\
\text { alfalfa } \\
\text { haylage }\end{array}$ & Barley & $\begin{array}{l}\text { Dry distillery grains, } \\
\text { whey wet and } \\
\text { permeate, rice bran, } \\
\text { wheat middling and } \\
\text { bran }\end{array}$ \\
\hline$<25$ & $\begin{array}{l}\text { Wheat } \\
\text { and/or } \\
\text { oat } \\
\text { silage, } \\
\text { sorghum } \\
\text { hay and } \\
\text { silage, } \\
\text { pastures }\end{array}$ & $\begin{array}{l}\text { Soybean } \\
\text { seeds }\end{array}$ & $\begin{array}{l}\text { Soybean meal, } \\
\text { sugar beet pulp, soy } \\
\text { hulls, corn gluten } \\
\text { feed and meal, corn } \\
\text { germ, citrus pulp, } \\
\text { sunflower meal, } \\
\text { bakery, raisins, grain } \\
\text { screening }\end{array}$ \\
\hline
\end{tabular}

cottonseed and canola meal (table 1). Between $50 \%$ and $75 \%$ of the dairies also used almond hulls. Almost 30 other different feeds (forages, grains and byproducts) were used in less than $50 \%$ of the dairies. Most of the dairy farms in Merced County were using only five dietary ingredients for lactating cows. An important proportion of animals were fed with different byproducts (table 1); this has important environmental implications because these byproducts cannot be used for human consumption but they are transformed into high-quality food (milk and milk products) by the dairy cows.

\section{Minerals in water and diets}

Drinking water. Dairy farms pump underground water for animal consumption. We used information from the NRC, U.S. EPA and World Health Organization to establish the upper desired intake levels in water for dairy cows; these levels should be considered a guideline, over which animals may be consuming and excreting excessive amounts of minerals. In our survey of 51 dairies, only $14 \%$ of the water samples were saline, with TSS greater than 1,000 milligrams per liter (mg/L). Eight minerals were in excess of the desired levels (table 2).

TABLE 2. Mineral composition of water troughs on Merced County dairy farms $(n=51)$

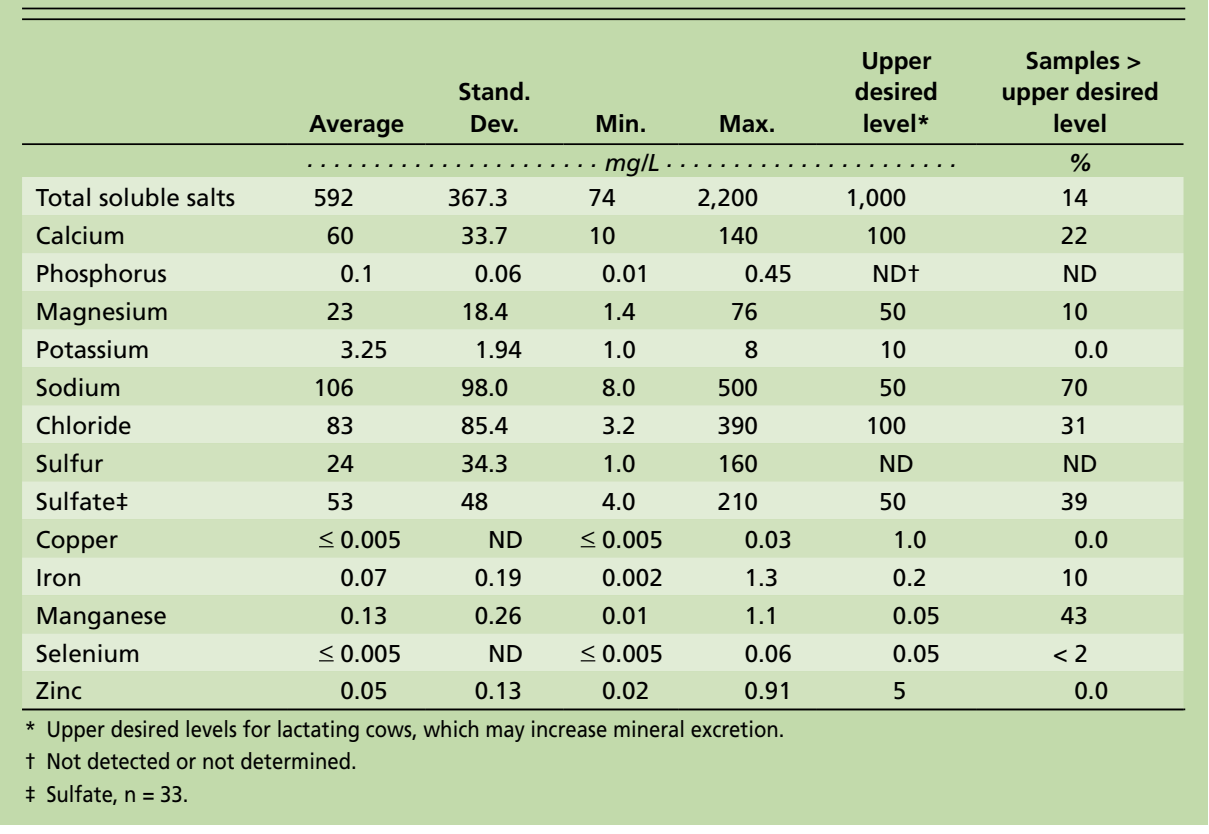

Our results for mineral concentrations from drinking water were similar to a previous survey of 101 samples collected from dairy farms throughout California (Socha et al. 2002). These authors indicated that the minerals of greatest concern in California were sodium and manganese, which exceeded the desired livestock levels in $64 \%$ and $41 \%$ of the water samples, respectively. We found a similar trend, but with greater values not only for sodium and manganese, but also for chloride and sulfates.

The results of this study on daily dietary mineral intakes, the contribution of minerals in the water and the final excretion for each mineral are presented in table 3, which shows the average daily dietary intake of each mineral for lactating dairy cows on the 51 dairies, the proportion of minerals consumed from the drinking water, and the estimated daily mineral excretion per cow.

Calcium. The average dietary calcium contents that we found were close to the requirement for cows producing 66 pounds ( 30 kilograms) of milk daily. The requirements for absorbed calcium that must enter the extracellular compartment for maintenance and production are fairly well known (NRC 2001); therefore, we expected the calcium excretion calculated in this survey to be close to the real calcium excretion. In our study, the average contribution of calcium from drinking water relative to total calcium excretion was low, about $4 \%$.

Phosphorus. The concentration of phosphorus in water averaged 0.11 milligram per liter in our study, representing a small contribution to total phosphorus intake and excretion. These values for phosphorus content in the diet were similar to those found by Satter et al. (2002) and Dou et al. (2003) for U.S. dairy diets. The estimations of phosphorus excretion in table 3 are similar to values reported by $\mathrm{Wu}$ (2005) and Weiss and Wyatt (2004).

Magnesium. Magnesium levels in the diets of cattle that we studied were in the same range as Weiss (2004). Weiss compiled data from eight experiments with lactating animals under different feeding conditions, and measured magnesium digestibility using the total collection of feces and urine. The author concluded that the apparent digestibility of magnesium was 30\% lower than the mean value calculated by the NRC model. The reason for this lower digestibility of magnesium was the high concentration of dietary potassium. Weiss observed that cows had to consume an additional 18 grams of magnesium per day for every 1 percentage unit increase in dietary potassium above $1 \%$, to maintain the same intake of digestible mag- 


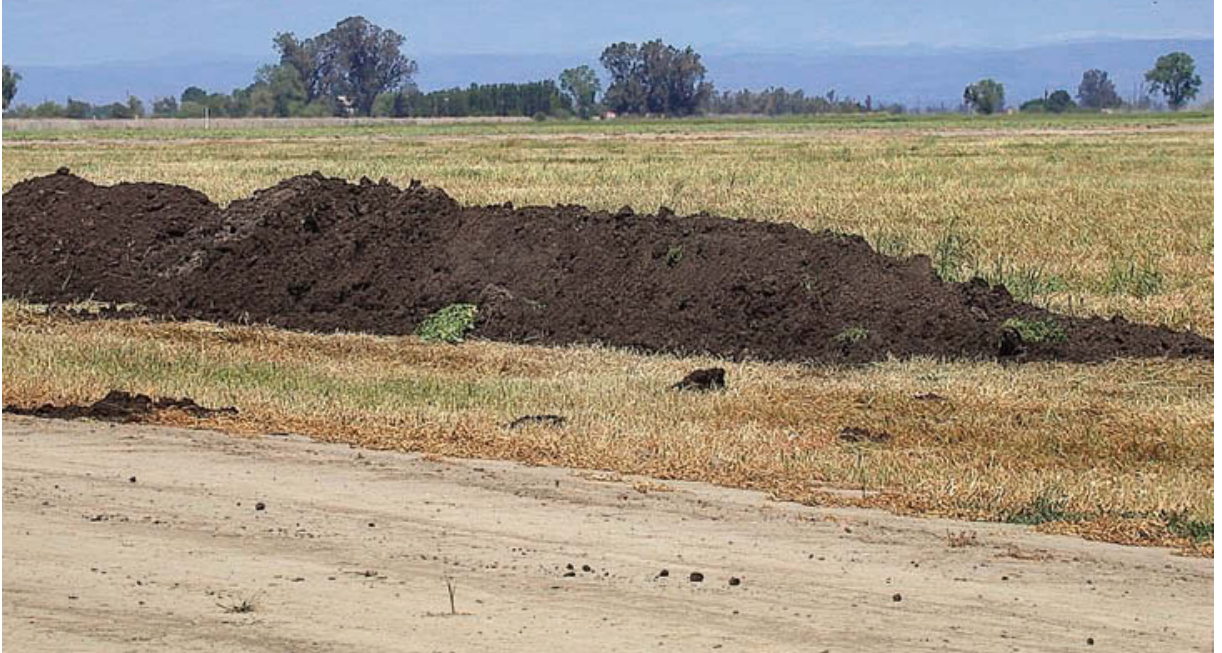

Dairy producers often apply manure to fields, where excess nutrients can run off into surface- and groundwater. Better estimates of mineral balances can improve animal performance and protect the environment.

nesium as that consumed when dietary potassium is $1 \%$. These results, and the mean concentration of potassium observed in our survey $(1.6 \%)$, indicate that the magnesium excretion figures in table 3 should be taken with caution. We found that the average impact of magnesium in the water on magnesium intake was $3.2 \%$.

Potassium. The daily excretion of potassium in this survey was estimated to be almost 300 grams per cow. This is 100 grams per cow lower than Grant (1997) found for cows producing 70.4 pounds (32 kilograms) of milk per day with $1.2 \%$ potassium in the diet. This can be explained by the differences observed in potassium dietary contents. The potassium in the drinking water was low, making an insignificant contribution to the diets and excretion (table 3).

Sodium and chloride. Daily intakes of sodium and chloride in the cow diets were high with respect to the NRC recommendations, and also highly variable. These variations may have been related to difficulties in obtaining good estimations of the salts that cattle are permitted to consume freely on some farms. However, the dietary concentrations of sodium and chloride in our study were comparable to those obtained in an extensive literature review by Sanchez et al. (1994).
Of all the minerals evaluated in water, sodium made the greatest contribution to the total daily excretion, averaging almost $17 \%$ of the mean sodium excreted. The daily excretion of sodium (64 grams per cow) in our survey was comparable to that found by Bannink et al. (1999), which estimated daily sodium excretions of 56 grams per cow from 10 feeding trials with lactating cows producing 55.4 pounds (25.2 kilograms) of milk per day.

The mean contribution of chloride in water to chloride excretion was $12 \%$. In spite of the cows' ability to consume excess sodium and chloride with limited impacts on performance, the contributions of these minerals to the environment, such as soil salinization, should be considered. The NRC suggested that more research is needed to establish the requirements and appropriate concentrations of sodium and chloride in dairy cattle diets. Nonetheless, the interaction of sodium and chloride with other minerals should be considered when formulating dairy cattle diets, to substantially reduce the amounts of sodium and chloride supplemented and excreted (Sanchez et al. 1994).

Sulfur. The NRC set the sulfur requirement at $0.20 \%$ of dietary dry matter (DM), suggesting that the maximum tolerable level should remain at $0.40 \%$ of dietary dry matter, with higher concen-

\begin{tabular}{|c|c|c|c|c|c|c|c|c|c|c|c|c|}
\hline \multicolumn{13}{|c|}{$\begin{array}{l}\text { TABLE 3. Estimates of daily mineral intake, drinking-water mineral contribution } \\
\text { and net mineral excretion in lactating cows on Merced County dairy farms }(n=51)\end{array}$} \\
\hline & \multicolumn{4}{|c|}{ Daily intake* } & \multicolumn{4}{|c|}{ Water contributiont } & \multicolumn{4}{|c|}{ Excretion¥ } \\
\hline & Mean & SD & Min. & Max. & Mean. & SD & Min. & Max. & Mean & SD & Min. & Max. \\
\hline & $\cdots \cdots$ & $\cdots$ & & & $\cdots$ & - gram & w/day & $\ldots \ldots$ & $\ldots \ldots$ & $\cdots \cdots$ & & $\cdots$ \\
\hline Calcium & 186 & 39.6 & 97 & 299 & 5.5 & 3.4 & ND & 15 & 150 & 36.3 & 72 & 247 \\
\hline Phosphorus & 96 & 19.5 & 57 & 142 & ND§ & ND & ND & ND & 69 & 17.1 & 39 & 114 \\
\hline Magnesium & 71 & 14.7 & 41 & 112 & 2.3 & 1.9 & ND & 8 & 67 & 14.5 & 39 & 106 \\
\hline Potassium & 338 & 51.6 & 236 & 520 & ND & ND & ND & ND & 297 & 48.8 & 211 & 485 \\
\hline Sodium & 83 & 31.8 & 8 & 173 & 10.6 & 10.0 & ND & 51 & 64 & 30.7 & 26 & 153 \\
\hline Chloride & 104 & 26.8 & 54 & 168 & 8.4 & 12.9 & ND & 83 & 71 & 26.8 & 15 & 140 \\
\hline \multirow[t]{2}{*}{ Sulfur } & 59 & 11.2 & 40 & 87 & 2.4 & 3.2 & ND & 14 & 16 & 9.4 & 1 & 40 \\
\hline & $\cdots \cdots$ & $\ldots \ldots$ & $\ldots \ldots$ & $\ldots \ldots$ & $\ldots \ldots$ & $\cdot m g / c$ & /day. & $\ldots \ldots$ & $\ldots \ldots$ & $\ldots \ldots$ & $\ldots \ldots$ & $\ldots \ldots$ \\
\hline Copper & 326 & 139.2 & 123 & 772 & 0.5 & 0.4 & ND & 2.3 & 322 & 138.9 & 119 & 767 \\
\hline Iron & 4,232 & 985.9 & 1,657 & 6,534 & 10.8 & 49.1 & ND & 355.4 & 4,201 & 982.6 & 1,627 & 6,495 \\
\hline Manganese & 1,457 & 491.5 & 573 & 2,459 & 10.2 & 22.1 & ND & 101.5 & 1,456 & 491.4 & 572 & 2,459 \\
\hline Selenium & 8 & 2.8 & 4 & 15 & 0.5 & 0.1 & ND & 0.7 & 1.4 & 2.56 & -3 & 9 \\
\hline Zinc & 1,489 & 579.0 & 559 & 2,720 & 11.2 & 52.5 & ND & 377.4 & 1,375 & 569.3 & 480 & 2,592 \\
\hline \multicolumn{13}{|c|}{$\begin{array}{l}\text { t Estimate based on mineral contents in drinking water and daily drinking-water intake, calculated using NRC (2001) recommended formula. } \\
\text { ‡ Excretion (feces + urine) = total dietary supply - total absorbed required for gestation, lactation and growth (NRC 2001). } \\
\text { § ND = not detected. }\end{array}$} \\
\hline
\end{tabular}




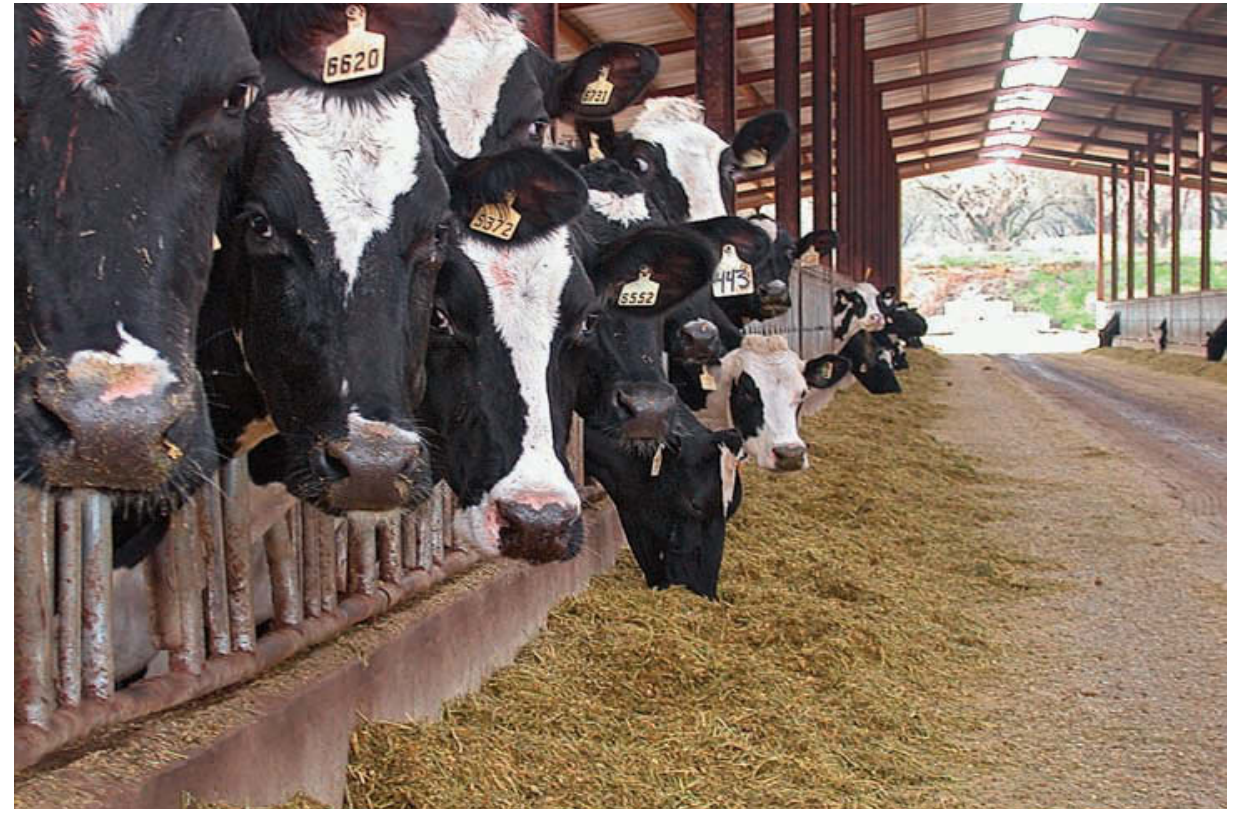

Dairy producers need information on the nutritional composition of cattle feeds, including complete mineral analyses, as well as access to analytical methods for estimating the minerals that cows may obtain from water.

trations being potentially detrimental to the absorption of copper and selenium. In our study, the mean dietary sulfur concentration was $0.27 \%$, ranging from $0.20 \%$ to $0.40 \%$. Ivancic and Weiss (2001) studied the dietary effect of sulfur and selenium concentrations in lactating dairy cows, and concluded that increasing sulfur in the diet (for example, by $0.21 \%, 0.41 \%$ and $0.70 \%$ ) significantly reduced dry matter intake, as well as yields of milk, milk protein and milk fat. This negative effect was larger when cows were fed 0.271 parts per million (ppm) compared with $0.135 \mathrm{ppm}$ of selenium. The mean water contribution of sulfur excretion in our survey was $15 \%$. On some farms, sulfur from water must be included in the diet to decrease excretion, minimize interactions with other minerals such as selenium, and minimize possible negative effects on lactation performance. Our estimation of daily sulfur excretion was $16 \pm$ 9.4 grams per cow.

Copper. Based on the zinc, calcium and sulfur contents of the cattle diets that we studied, some interactions with copper absorption were expected (NRC 2001; Spears 2003; Beede 2005). The mean dietary concentration of copper in rations from the farms analyzed in our study was 15 milligrams per kilogram. This concentration was 2.7 times lower than the established upper limit of 40 milligrams per kilogram, and 35\% more than the NRC's suggested requirement (11 milligrams per kilogram). We found that the contributions of copper from drinking water and the diet to this mineral's overall excretion were low. However, daily copper intake and excretion were highly variable, ranging from 123 to 772 and 119 to 767 milligrams per cow, respectively.

Iron. Iron can interfere with absorption of copper and zinc when dietary levels are over 250 milligrams per kilogram dry matter (NRC 2001). In our study, the average concentration of iron was below 200 milligrams per kilogram dry matter, but about $10 \%$ of the dairy farms had high dietary levels of this mineral. The mean contribution of iron from drinking water to total iron excretion was very low. Daily iron excretion averaged 4,201 \pm 983 milligrams per cow based on its coefficient of absorption, which the NRC set at 10\% in feedstuffs for adult animals.

Manganese. Recently, Weiss and Socha (2005) estimated the maintenance requirements of dairy cows for manganese. The authors concluded that the dietary requirements were 1.6 and 2.7 times higher for lactating and dry cows, respectively, compared to those calculated with the NRC model. Daily manganese consumption in our survey averaged $67.1 \pm 22.8$ milligrams per kilogram dry matter (ranging from 23 to 142 milligrams per kilogram). These amounts can apparently support main- tenance and production requirements for manganese with no negative effects on the animal. Despite the high concentrations of manganese in some water samples (table 2), the average contribution of manganese from water to total diet and excretion was insignificant or less than $1 \%$ (table 3). Daily estimated manganese excretion was 1,456 milligrams per cow, ranging from 572 to almost 2,459 milligrams per cow.

Selenium. Current regulations established by the U.S. Food and Drug Administration (FDA) limit selenium supplementation to 0.3 milligram per kilogram of diet. The mean values obtained in our survey were $20 \%$ over that limit. These differences could be explained by the lack of data on the selenium content of feeds. Assuming that most feedstuffs contain some selenium, it is expected that total mixed rations contain concentrations above the recommended level. Possible interrelationships between nutrients that may affect the absorption and metabolism of selenium would alter the requirement for this mineral (NRC 2001; Ivancic and Weiss 2001). The NRC concluded that data concerning the interaction between zinc and selenium is lacking. We found that the estimated average contribution of selenium excretion from water was $35 \%$. The daily excretion of selenium was highly variable, averaging $1.4 \pm$ 2.6 milligrams per cow. This value could also be related to the methodology used to estimate the efficiency of dietary selenium utilization by the animals.

The NRC found that the factorial approach is problematic for establishing selenium requirements because of how selenium is deposited in body tissues. As cows consume more selenium, its concentration in milk and the conceptus (the fetus and associated tissues) increases, indicating that selenium excretion in our survey was probably overestimated. A national meeting on selenium concluded that although minimum selenium requirements are well documented, continued research is needed to determine the optimum dietary requirements for humans and animals, to allow adequate function of the immune system and protect against infectious disease and physiological stress (Drake et al. 1995). 


\section{Minerals in the water may affect excretion of them, suggesting that water contributions must be controlled and incorporated when formulating animal diets.}

Zinc. Dietary zinc content in our survey was $68.2 \pm 25.8$ milligrams per kilogram dry matter. This amount is 5 milligrams per kilogram dry matter higher than the requirement set by the NRC for a cow producing 88 pounds (40 kilograms) of milk per day. In approximately $40 \%$ of the dairies that we studied, cows were fed more than 63 milligrams per kilogram dry matter, or 1,300 milligrams per cow per day of zinc. Also, in $12 \%$ of the dairies, zinc in the diet was too low, under the minimum recommendation (35 milligrams per kilogram dry matter). The mean content of zinc in drinking water was negligible, except at one dairy where 377 milligrams per cow was consumed daily from the water, representing $28 \%$ of the mean excretion. The estimated daily excretion of zinc ranged from 480 to 2,592 milligrams per cow.

Analysis of all minerals. Based on the minerals analyzed in this study, a lactating dairy cow producing approximately 66 pounds (30 kilograms) of milk per day might excrete $750 \pm$ 117 grams of minerals per day, ranging from 451 to 1,019 grams per cow per day. The proportion coming from the water represented a mean of $4 \% \pm$ $3.3 \%$ (ranging from $0.3 \%$ to $20 \%$ ). On some dairies, controlling these amounts could reduce manure production and therefore minerals in land applications. The results of our survey indicate that minerals in the water may affect excretion of them, suggesting that water contributions should be controlled and included when formulating animal diets to manage mineral balances and reduce mineral excretion. When an unmanageable excess of minerals coming from water affects soil quality (for example, salinization) or animal performance, other methods to improve water quality should be analyzed (filtration, reverse osmosis and so on).

\section{Obtaining accurate information}

In order to obtain accurate estimates of mineral balances in dairy herds to optimize animal performance and minimize the environmental impacts caused by the excessive excretion of minerals - more detailed information is needed about mineral concentrations in feeds, including the differences between forages, grains and byproducts. Better access to analytical methods for measuring trace minerals would help in formulating animal diets, as would the publication of nutrient compositions in feeds, with complete mineral analyses. For those minerals that receive a substantial contribution from water - such as, in this study, sodium and chloride - water analysis would allow nutritionists to minimize the use of supplemental sources such as freechoice salts.

Although selenium is the only mineral regulated by the FDA, little is known about its content in dairy cow feeds. This lack of knowledge may, in many instances, force nutritionists to not even consider contributions from dietary ingredients other than the

\section{References}

Bannink AH, Van Vuuren AM. 1999. Intake and excretion of sodium, potassium, and nitrogen and the effects on urine production by lactating dairy cows. J Dairy Sci 82:1008-18.

Beede DK. 2005. The most essential nutrient: Water. In: Proc 7th Western Dairy Manag Conf. Reno, NV. p 13-31.

Challis DJ, Zeinstra JS, Anderson MJ. 1987. Some effects of water quality on the performance of high yielding cows in an arid climate. Vet Rec 120:12-5.

Chase LE. 2002. Water quality and quantity for dairy cattle. In: Proc Cornell Nutr Conf. Syracuse, NY. p 197-203.

Dou Z, Ferguson JD, Fiorini J, et al. 2003. Phosphorus feeding levels and critical control points on dairy farms. J Dairy Sci 86:3787-95.

Drake DJ, Hubard C, Maas J, et al. (eds.). 1995. Proc Natl Symp on Selenium in the Environment: Essential Nutrient, Potential Toxicant. UC Davis, Cooperative Extension. Sacramento, CA. p 65-8.

Grant R. 1997. Feeding dairy cows to reduce nitrogen, phosphorus, and potassium excretion into the environment. http://ianrpubs.unl.edu/dairy/g1306.htm.

Ivancic Jr J, Weiss WP. 2001. Effect of dietary sulfur and selenium concentrations on selenium balance of lactating Holstein cows. J Dairy Sci 84:225-32.

Murphy MR. 1983. Factors affecting water consumption by Holstein cows in early lactation. J Dairy Sci 66:35-8.

Murphy MR. 1992. Water metabolism of dairy cattle. J Dairy Sci 75:326-33.

Nennich TD, Harrison JH, VanWieringen LM, et al. 2005. Prediction of manure excretion from dairy cows. J Dairy Sci 88:3721-33.

[NRC] National Research Council. 2001. Nutrient Requirements of Dairy Cattle. (7th rev. ed.). Washington, DC: Natl Acad Pr. 408 p

Sanchez WK, McGuire MA, Beede DK. 1994. Macromineral nutrition by heat stress interactions in supplemental source. A software application is needed that allows ration formulas to integrate minerals from drinking water, indicate the excess minerals consumed, measure potential interactions among minerals that could affect animal health and performance, and estimate the daily excretion of minerals in feces and urine.

A.R. Castillo is Farm Advisor in Dairy Science, UC Cooperative Extension, Merced and Stanislaus counties; J.E.P. Santos is Associate Professor, School of Veterinary Medicine, Tulare (UC Davis); and T.J. Tabone works on statistics and biometry, College of Agriculture and Life Sciences, University of Wisconsin, Madison. The authors thank dairy producers in Merced County for their participation in the survey; John Kirk for his permanent support and John Maas for his critical review of the manuscript; Frank Mitloehner, Peter Robinson and Freerk Boersma for their help at the beginning of this survey.

dairy cattle: Review and original research. J Dairy Sci 77:2051-79.

Satter LD, Klopfenstein TJ, Erickson GE. 2002. The role of nutrition in reducing nutrient output from ruminants. J Anim Sci 80 (E Suppl 2):E143-56.

Socha MT, Ensley SM, Tomlinson DJ, et al. 2002. Variability of water composition and potential impact on animal performance. In: Proc Cal Anim Nutr Conf. Fresno, CA. p 81-91.

Solomon R, Miron J, Ben-Ghedalia D, et al. 1995. Performance of high producing dairy cows offered drinking water of high and low salinity in the Arava desert. J Dairy Sci 78:620-4.

Spears JW. 2003. Trace mineral bioavailability in ruminants. J Nutr 133:1509S.

[USDA] US Department of Agriculture. 2003 National Planning Procedures Handbook. Subpart E, Parts 600.50-600.54 and Subpart F, Part 600.75. Draft Comprehensive Nutrient Management Planning Technical Guidance. Natural Resources Conservation Service. Washington, DC. www.nrcs.usda.gov/ technical/afo/cnmp_guide_index.html

[US EPA] US Environmental Protection Agency. 2003. Concentrated Animal Feeding Operations (CAFO) - Final Rule. National Pollutant Discharge Elimination System. Washington, DC. http://cfpub.epa. gov/npdes/afo/cafofinalrule.cfm.

Weiss WP. 2004. Macromineral digestion by lactating dairy cows: Factors affecting digestibility of magnesium. J Dairy Sci 87:2167-71.

Weiss WP, Socha MT. 2005. Dietary manganese for dry and lactating Holstein cows. J Dairy Sci 88:2517-23.

Weiss WP, Wyatt DJ. 2004. Macromineral digestion by lactating dairy cows: Estimating phosphorus excretion via manure. J Dairy Sci 87:2158-66

Wu Z. 2005. Utilization of phosphorus in lactating cows fed varying amount of phosphorus and sources of fiber. J Dairy Sci 88:2850-9. 